Personalidade Acadêmica Homenageada:

Raymundo Juliano Feitosa (Universidade Federal do Rio Grande do Norte - UFRN)

\title{
O PROBLEMA DO ARMAMENTO DOS CIDADÃOS EM UM GOVERNO OPRESSOR
}

\section{THE PROBLEM OF ARMORING CITIZENS IN AN OPPRESSIVE GOVERNMENT}

\section{MARCELLA FERNANDA APARECIDA DIAS}

Graduando em Direito na modalidade Integral - Escola Superior Dom Helder Câmara, Belo Horizonte - MG. E-mail: diasmarcella15@gmail.com.

CAIO AUGUSTO SOUZA LARA Mestre e Doutor em Direito pela Faculdade de Direito da Universidade Federal de Minas Gerais - UFMG. Professor da Escola Superior Dom Helder Câmara. Pesquisador Associado ao Programa RECAJ-UFMG - Acesso à Justiça e Solução de Conflitos. Secretário de Comunicação do Conselho Nacional de Pesquisa e Pósgraduação em Direito - CONPEDI. Belo Horizonte - MG. E-mail: caiolarabh@yahoo.com.br.

\section{RESUMO}

O tema-problema da pesquisa que se pretende desenvolver é a adoção de mudanças normativas em prol do armamento dos cidadãos em um governo que possui um chefe de Estado e do Governo que abertamente apoia a tortura. Faz-se necessário abordar o desarmamento civil no contexto social brasileiro atual, visto que o governo o qual se encontra no poder apoia políticas arbitrárias que leva o indivíduo a ter seus direitos fundamentais (como a inviolabilidade do direito à vida) colocados em risco. A título de exemplo, temos a legalização do porte de arma, fato esse que, diante da experiência internacional, tende a aumentar o número de mortes e não a 
Personalidade Acadêmica Homenageada:

Raymundo Juliano Feitosa (Universidade Federal do Rio Grande do Norte - UFRN)

reduzi-las. Em contrapartida, a possível retirada de verbas destinadas à educação básica e às universidades brasileiras mostra o descaso para a promoção do senso crítico da população, que provém da efetivação do direito social à educação. Desta maneira, como o governo pretende manter a sociedade afastada da construção de seus próprios posicionamentos, os cidadãos ficarão à mercê das imposições do regime político em questão. O Brasil, no ranking mundial de homicídios, se encontra em décimo terceiro lugar e a maior parte dos homicídios provém da utilização incorreta das armas de fogos, que causa graves acidentes, principalmente em recintos domésticos. A tentativa de autodefesa por arma de fogo pelo cidadão comum, tem aplicação improficiente visto que aumenta o número de acidentes, causando assim o aumento no número de feridos na sociedade; e como sistema único de saúde do país não apresenta um amparo efetivo para com a população, essas pessoas ficariam sujeitas às agravações de seus casos, levando até mesmo elas a óbito. O problema objeto da investigação científica proposta é: qual a implicação do armamento dos cidadãos em uma sociedade em que o governo o qual eles estão submetidos apoia a tortura e a opressão? A partir das reflexões preliminares sobre o tema, é possível afirmar inicialmente que a concessão do armamento de cidadãos em meio social, provocará o caos, uma vez que segundo a declaração dos direitos humanos todos os indivíduos são possuidores do direito à vida e a utilização de tais objetos vai em contraposição a explanação. O objetivo geral do trabalho é analisar como a mudança do ordenamento jurídico que visa a flexibilização do acesso ao armamento do cidadão pode contribuir para o agravamento dos índices de violência no brasil. A pesquisa que se propõe pertence à vertente metodológica jurídico-dogmática. No tocante ao tipo de investigação, foi escolhido, na classificação de Witker (1985) e Gustin (2010), o tipo jurídico-projetivo. O raciocínio desenvolvido na pesquisa será predominantemente dialético. De acordo com a técnica de análise de conteúdo, afirma-se que se trata de uma pesquisa teórica, o que será possível a partir da análise de conteúdo dos textos doutrinários, normas e demais dados colhidos na pesquisa. A partir do exposto, conclui-se preliminarmente que 0 armamento da população irá gradativamente acarretar no genocídio de grande parte da população, especialmente dos povos historicamente oprimidos. Mulheres, negros, homossexuais e travestis são os 
Personalidade Acadêmica Homenageada:

Raymundo Juliano Feitosa (Universidade Federal do Rio Grande do Norte - UFRN)

principais perfis que encontraremos sendo afetado negativamente pela utilização das armas de fogo. As armas não trarão segurança para a sociedade. Enquanto o cidadão comum utilizar da violência para poder se resguardar, não atingiremos o bem comum. Logo, liberar o armamento para a população será mais um intensificador para a mazela social da violência no Brasil.

PALAVRAS-CHAVE: Armas; Homicídios; Ordenamento Jurídico; Governo; Direitos.

\section{REFERÊNCIAS}

BOBBIO, Noberto. Era dos Direitos. 7ª . Ed. Rio de Janeiro: Elsevier, 2004.

FIGUEIREDO. Danniel. Posse de arma; entenda esse conceito. Politize. 22 de janeiro de 2019. Disponível em: https://epoca.globo.com/ideias/noticia/2015/04/devemosliberar-armas-nao.html. Acesso em: 13 de abril de 2019.

FRANCO, Paulo Alves. Estatuto do Desarmamento. 3a. Ed. Campo Grande: Comtemplar, 2011.

GUSTIN, Miracy Barbosa de Sousa; DIAS, Maria Tereza Fonseca. (Re)pensando a pesquisa jurídica: teoria e prática. 3a․ ed. Belo Horizonte: Del Rey, 2010.

NUNES, Antônio José Avelãs. O neoliberalismo, o ataque ao estado social, os perigos do "fascismo de mercado". Revista Jurídica - UniCuritiba. Volume 3. 2013. Disponível em: http://revista.unicuritiba.edu.br/index.php/RevJur/article/view/677/503. Acesso em: 20 de maio de 2019.

SANINI, Francisco. Mais armas, menos crimes ou menos armas, mais crimes: uma reflxão sobre o armamento da sociedade civil. Jus Brasil. Março de 2019. Disponível em: https://jus.com.br/artigos/64856/mais-armas-menos-crimes-ou-menos-armasmenos-crimes-uma-reflexao-sobre-o-armamento-da-sociedade-civil Acesso em: 13 de abril de 2019.

SARON, Matias. Brasil é o país onde mais se mata com arma de fogo do mundo. Galileu. 31 de agosto de 2018. Disponível em: https://revistagalileu.globo.com/Sociedade/noticia/2018/08/brasil-e-o-pais-onde-maisse-mata-com-armas-de-fogo-no-mundo.html. Acesso em: 10 de maio de 2019.

WITKER, Jorge. Como elaborar una tesis en derecho: pautas metodológicas y técnicas para el estudiante o investigador del derecho. Madrid: Civitas, 1985. 